\title{
Farmers in the Driving Seat of Agricultural Control
}

\author{
R De Kok* \\ Monitoring Agricultural Resources Unit, European Commission, Belgium
}

Submission: December 21, 2017; Published: February 01, 2018

"Corresponding author: R De Kok, Monitoring Agricultural Resources Unit, European Commission, Belgium, Email: roeland_de_kok@hotmail.com

\section{Introduction}

The year 2017 has brought us profound changes and some of them were initiated by the EU and ESA in the domain of observation of the earth within the Copernicus program. With the availability of free satellite data at short temporal intervals, the Sentinel satellite fleet of ESA is delivering daily data at global level [1].

Although some changes might be perceived as 'more of the same', the scale of change might have a tipping point, where the effects flows over from the domain of specialists to 'common users'. This phenomenon is already known in the use of GPS measurements, which allows the dissemination of position accuracy, once reserved to survey specialist, towards the average (agricultural) user. We have seen this happening in for example the use of the mobile phone and the laptop computer. All of them having predecessors in a limited professional domain in past decades. For earth observation and agricultural control, this comes with both a potential change in users, as well as a larger public becoming more and more familiar with 'Big Data'.

Control of agriculture with remote sensing is not a daily task at farm level. Farming is about primary production. If you are a primary producer, the product take shape through your hands. This is a base for pride. The appreciation however is 'out of your hands'. If you would produce the best blue apples of the country and would not find a single buyer or maybe only one specialist, your pride would be that of an artist, instead of that of a farmer. Producer, pride and appreciation are basics to agriculture. Then where does it leave us with control? Control may be essential but is neither a base for pride nor that of appreciation. It is a necessity, close at par with death and taxes.

What has changed in 2017? The level of control as well as the scale of data has become more accessible to non-experts, mainly due to pricing and further development of open source software. The effects of 'Big Data is still under development [2]. It can be a hard task to prepare non-specialist users to deal with 'Big Data' in primary production. How to treat an hourly temperature reading of every square meter on the parcel? What is it of help to know the hourly position of every animal or the daily increment in biomass on a potato field? Earth observation of agricultural land might lead to produce a lot of redundant information, but dissemination among non-specialist users also might trigger complete new dynamics.

This would imply that the knowledge on non-linear systems would find a way to the general public. The accessibility of internet based videos on complex networks already give indications in this direction. This is a new domain of modelling, predicting outcome of primary production processes as well as market appreciations on products. However, in this short review, lets remain at the level of earth observation.

Satellites for observing the earth were developed already in the era of president Kennedy. But what's new today? It is the price of information on every agricultural parcel. It has never been so cheap to monitor completely the national agricultural development during the season. Every hectare on earth can now be evaluated with more reliability, if the parcel is subject to agricultural production or not [3], at zero cost for the satellite imagery itself.

In the European context, the impact might be on control. Now, the EU budget is for a very large part structured around the income support for farmers. Curiously, the control on spending this budget is a governmental task. This made sense in an era when data, information and expertise were all expensive and only specialist in governmental service were involved. With modern developments in remote sensing, there is an opening for another vision, in the sense, that the agricultural domain takes over the agricultural control. Just like notary and medical doctors have their peer reviewed control, it is possible with modern earth observation data, that control tasks by governments are transferred to the organisation of (agricultural) producers themselves.

In the end, government only needs to receive feedback, if the budget intended for income support is effective. Indicator values should be sufficient to monitor if (families of) farmers are able to own a living in modern agriculture and maintain the ownership of their lands. A control body with adequate budget, with or 
without government in the driving seat, is always able to buy land, support income, initiate and reconstruct family business and keep primary production in line with desired policy.

The control body is only responsible to the taxpayer's money in showing the final statistical result of farmer's families being able to produce in a changing market, without losing or eroding their basis for production. In the very end, the agricultural potential of European soils should not be compromised. Nor should environment and landownership develop into a negative spiral.

As production comes with pride and appreciation is something to wish for, the thankless task of control should be an inherent task of the total production chain. Leaving the thankless task to government alone erodes a relation of trust in the long term.

The hidden agenda that are foreseen by stakeholders is the risk of a consequent lower budget for European agriculture. As the discussion around the Brexit shows, a large part of for example pension obligations are perceived as a cost, where in practice, a large part of this money is flowing back into UK economy through the pensionaries living there. The Brexit opens the discussions around perceived as well as real costs within the EU. The perceived and real cost of agricultural support within the EU are obscured through the effective low prices for agricultural products at the consumer's level. The price that the EU consumers have to pay for food in the supermarket is disconnected from agricultural cost integrated into taxes. The Brexit reveals the perceived and real costs for the EU. First, this might change UK policy, if UK taxpayers would claim other priorities in the national budget.
The support for present EU obligations now and in the near future are at risk of re-evaluations too. As the Brexit discussion requires a thorough explanation on real and perceived costs and budget commitments. This explanation clarifies, which commitment are perceived as anachronism not to be taken up into future obligation. The Brexit dynamic might lead to a reevaluation of the EU budget too, with unforeseen consequences for the agricultural support [3].

A control body of agricultural peers has a natural credibility in explaining the real cost of income support of their members. Such a structural organisation is a credible body to defend the necessary budget for effective income support.

Visions and models related to new technological developments, or moreover the scale of technological developments might be divers. The perceived and real cost of the Brexit, the dominant role of the agricultural support in the EU budget and the way to use new technology to control are subject to profound changes and require initiatives from stakeholders involved. Proactive visions are thus required.

\section{References}

1. Lemoine G (2016) Detection and Monitoring of Agricultural Land Conversion using Copernicus Sentinel 1 and 2, Case Study of Gambella State (Ethiopia). European Commission JRC, Ispra, Italy.

2. Lemoine G (2016) Monitoring Agriculture with Remote Sensing (MARS) A focus on agricultural user requirements-Serving society Stimulating innovation Supporting legislation. European Commission, JRC, Ispra, Italy.

3. R de Kok P, Wężyk M, Papież, Migo L (2017) Applications of Sentinel-2 data for agriculture and forest monitoring using the absolute difference (ZABUD) index derived from the Agro Eye software (ESA). Proc. SPIE 10421, Remote Sensing for Agriculture, Ecosystems, and Hydrology XIX, 104211A
Your next submission with Juniper Publishers will reach you the below assets

- Quality Editorial service

- Swift Peer Review

- Reprints availability

- E-prints Service

- Manuscript Podcast for convenient understanding

- Global attainment for your research

- Manuscript accessibility in different formats

( Pdf, E-pub, Full Text, Audio)

- Unceasing customer service

Track the below URL for one-step submission https://juniperpublishers.com/online-submission.php 